\title{
PENANGANAN KESEHATAN UNTUK ORANG LANJUT USIA
}

Nama: Muhammad.Alvin.Arkananta.Syam

Email: alvinas2751@gmail.com

Pemerintah Indonesia memberlakukan sebuah peraturan yang dibutuhkan setiap komunitas lokal untuk membuat jasa Kesehatan bagi yang sudah lanjut usia. Kepemimpinan dalam komunitas berperan penting dalam membuat layanan perawatan jangka panjang agar tersedia. Meningkatkan Jasa pelayanan dengan kegiatan keagamaan penting untuk meningkatkan keterimaan/penerimaan, akan tetapi juga perlu mempertimbangkan prinsip universalitas (secara terbuka) dan nondiskriminasi. Pada artikel ini hasil analisis menunjukkan bahwa layanan perawatan jangka panjang sulit untuk diperluas dan standar kualitas sulit untuk ditingkatkan mungkin karena beberapa masyarakat yang mau memberikan layanan secara sukarela kurang, dukungan dari para pemimpin agama juga bisa dibilang tidak banyak, sumber daya yang terbatas dan pelatihan relawan yang tidak memadai.

Dehidrasi kekurangan air biasa terjadi Ketika cairan yang keluar melebihi jumlah masuknya cairan dan bisa menyebabkan meningkatnya serum osmolalitas (Merupakan jumlah solute dalam tiap satu kilogram pelarut), Hal ini cukup umum terjadi pada orang tua yang tinggal di fasilitas perawatan jangka panjang. Penghuni fasilitas perawatan jangka panjang sangat rentan terhadap dehidrasi karena mereka lebih memungkinkan untuk mengalami sebuah masalah kognitif dan fisik yang bisa mempengaruhi kemampuan mereka untuk mengingat dan mendapatkan cairan yang dibutuhkan. Artikel ini masih belum dapat menunjukkan keefektivitasan strateginya dikarenakan kurangnya intervensi untuk mengidentifikasi dan menargetkan sebuah hambatan pribadi orang lanjut usia untuk meminum air, sehingga hanya mempromosikan perawatan yang berfokus pada perorangan saja. Diperlukan juga dukungan penelitian yang memadai untuk mengembangkan penelitian berkualitas tinggi di panti jompo untuk meningkatkan asupan cairan dan status dehidrasi pada penghuni panti jompo yang lebih tua (Bunn, Jimoh, \& Wilsher, 2015).

Disini Saya akan mewawancarai Nenek dari pihak Ibu saya, Nama Nenek Saya Siti Yulianti, umur 66 tahun, Pendidikan terakhir PDA, sekarang tinggal di Kabupaten Gresik Provinsi Jawa Timur dan tinggal Bersama Ibu dan Om saya. Masalah Kesehatan yang sedang dihadapi nenek saya hanyalah penyakit lewat atau gejala ringan seperti batuk, maag, pusing pilek dan sebagainya. Untuk tanggapan Nenek saya terhadap mendapatkan layanan Kesehatan yaitu sangat tidak enak, dikarenakan sangat mengganggu, disetiap waktu yang ditentukan akan dicek kondisi tubuh, kelembaban udara kamar, kebersihan perabotan kamar inap rumah sakit dan diantar makanan, setiap kali masuk pun selalu ditanyakan bagaimana keadaannya dan butuh apa sehingga menurut nenek saya lebih baik tinggal dirumah dirawat oleh anak sendiri ketimbang di rumah sakit. Dan untuk layanan di saat masa Pandemi dikatakan lebih parah dibandingkan saat normal, membuat nenek saya makin lama makin tidak betah di rumah sakit karena ditanyakan pertanyaan privat mulai dari terakhir pernah keluar negeri dengan siapa saja dan akhir-akhir ini siapa yang sering ditemui.

Untuk Prinsip-Prinsip yang ada di artikel Pratono \& Maharani (2018) ada beberapa yang telah terpenuhi dan belum terpenuhi, Untuk yang terpenuhi seperti ketersediaan yang lengkap dan jika ada yang kurang tinggal minta bantuan ke perawat, aksesibilitas yang memudahkan untuk pengunjung mengunjungi orang sakit, dan kualitas rumah sakit yang tentunya tidak main-main. Untuk prinsip-prinsip yang belum terpenuhi seperti kemampuan beradaptasi ini terjadi karena adanya ketidaknyamanan pasien terhadap seringnya perawat keluar masuk untuk mengecek pasien dan universalitas. 


\section{Reference}

Bunn, M., Jimoh, P., \& Wilsher, P. H. (2015). Increasing Fluid Intake and Reducing

Dehydration Risk in Older People Living in Long-Term Care: A Systematic Review. JAMDA, 16, 101-113.

Pratono, A.H. \& Maharani, A. (2018). Long-term care in Indonesia: The role of integrated service post for elderly. Journal of Aging and Health, 30(10) 1556-1573 